\title{
Evaluation of seed physiological quality of papaya elite hybrids, their reciprocal crosses and parents ${ }^{1}$
}

\author{
Célia Maria Peixoto de Macedo ${ }^{2 *}$, Messias Gonzaga Pereira ${ }^{3}$, \\ Deisy Lúcia Cardoso ${ }^{3}$, Roberto Ferreira da Silva²
}

\begin{abstract}
This study aimed to evaluate the physiological quality of seeds of three hybrid combinations and their reciprocals, as well as the selfed parents, and to estimate genetic parameters associated with seed quality, and possible reciprocal effects. The experiment used $\mathrm{F}_{1}$ hybrid papaya seeds and their reciprocal crosses between JS12 and Sunrise Solo 72/12, Sekati and Waimanalo, and the seeds of the parents and two varieties, totaling 12 treatments in a completely randomized design with four replications. Weight of 1,000 seeds, germination, seedling fresh weight and seedling dry weight, first count, speed of germination and seedling emergence were determined. There was no xenia effect for weight of 1,000 seeds and seedling fresh weight. The reciprocal effect was not expressed for germination and seedling emergence, while for the other traits, it was not expressed only for JS12 x Sekati. Differences among hybrids and their parents occurred as a result of the action of pollen in the crosses, and justified by early heterosis. The most sensitive vigor tests to discriminate differences in performance of hybrids and their reciprocals were speed of germination and seedling fresh weight. There were high magnitudes of the estimates for the genotypic determination coefficient for most of the evaluated variables, except for seedling fresh weight.
\end{abstract}

Index terms: Carica papaya L., maternal effect, reciprocal effect, early heterosis, genetic parameters.

\section{Avaliação de híbridos elite de mamão, de seus recíprocos e respectivos genitores, quanto à qualidade fisiológica de sementes}

RESUMO - O objetivo do presente trabalho foi avaliar a qualidade fisiológica das sementes de três combinações híbridas e seus recíprocos, além dos genitores autofecundados; estimar parâmetros genéticos associados à qualidade fisiológica, bem como possíveis efeitos recíprocos. Foram usadas sementes híbridas $\mathrm{F}_{1}$ de mamão e seus respectivos recíprocos, provenientes dos cruzamentos JS12 com Sunrise Solo 72/12, Sekati e Waimanalo, e sementes dos genitores e duas cultivares, totalizando 12 tratamentos em delineamento experimental inteiramente casualizado com quatro repetições. Determinou-se a massa de mil sementes, germinação, massa fresca e massa seca de plântula, primeira contagem e velocidade de germinação e emergência de plântula. Houve ausência de xênia para massa de mil sementes e massa fresca de plântula. $\mathrm{O}$ efeito recíproco não se manifestou para germinação e emergência de plântula, sendo que para as demais características somente não se manifestou para JS12 x Sekati. Diferenças entre híbridos e genitores ocorreram em razão da ação do pólen no cruzamento, explicado pela heterose precoce. Os testes de vigor mais sensíveis para discriminar diferenças no desempenho dos híbridos e seus recíprocos foram velocidade de germinação e massa fresca de plântula. Verificaram-se magnitudes altas das estimativas do coeficiente de determinação genotípica para maioria das variáveis avaliadas, à exceção para massa fresca de plântula.

Termos para indexação: Carica papaya L., efeito materno, efeito recíproco, heterose precoce, parâmetros genéticos.

\section{Introduction}

Brazil is the world's largest producer of papaya, with an annual production of $1,792,594 \mathrm{t}$ in 2009 , a decrease of $5.2 \%$ compared to the 2008 harvest. The harvested area totaled 34,213 ha, and the average harvested yield was 52,396 kg.ha-1 (IBGE, 2011).

In the state of Espírito Santo, the seeds from the group

${ }^{1}$ Submitted on 06/27/2012. Accepted on 01/31/2013.

${ }^{2}$ Laboratório de Fitotecnia, UENF, 28013-602 - Campos dos Goytacazes, RJ, Brasil.
Solo used in commercial crops of papaya come mostly from farmers' own cultivation while those of group Formosa are imported at high costs (Lopes et al., 2008). However, the dependence on imported seeds can now be reduced as a result of the release of hybrid UENF/Caliman 01. This was one of nine hybrids whose production was based on the study by Marin et al. (2006), who used partial diallel crosses to determine

\footnotetext{
${ }^{3}$ Laboratório de Melhoramento e Genética Vegetal, UENF, 28013-602 Campos dos Goytacazes, RJ, Brasil.

*Corresponding author <celiamariapeixoto@bol.com.br>
} 
combining abilities and identify promising hybrid combinations.

Seeds are one of the most important resources for plant breeding; they are also the traditional propagation medium to establish commercial papaya plantations in Brazil, although this culture can also be propagated by vegetative methods. According to Berbert et al. (2008), papaya seeds behave more similarly to orthodox seeds, whose viability is extended by simultaneously reducing water content and temperature during storage. This behavior has advantageous implications for preserving germplasms for extended periods of time.

One way for seed producers to optimize controlled pollination is to implement reciprocal crosses whereby a genotype is used sometimes as a female, sometimes as a male, if such crosses result in F1 hybrid seeds and reciprocal seeds with similar performance for physiological seed quality. Because this performance is heavily dependent on the genetic nature of the seeds so that vigorous seedlings can be produced, the present study, which focuses on the physiological quality of papaya seeds derived from crosses and their reciprocals, can provide a significant contribution.

High values of coefficients of genetic variation among genotypes $(\mathrm{CVg})$ - for some traits associated with physiological quality of papaya seeds - were found in another study, suggesting that there may be significant gains in selecting seed quality (Cardoso et al., 2009). Furthermore, estimates of heritability also showed selection to be an advantage.

The aim of this study was to evaluate the physiological quality of seeds of three elite hybrids, their reciprocals and the selfed parents, as well as estimate genetic parameters associated with seed quality and possible reciprocal effects among the papaya hybrids studied.

\section{Material and Methods}

This study started at the experimental area of farm Santa Teresa, owned by company Caliman Agrícola S/A, located in Linhares, in the state of Espírito Santo. Then, it continued in the Plant Science Laboratory of the Center for Agricultural Science and Technology of the Universidade Estadual do Norte Fluminense 'Darcy Ribeiro' (CCTA / UENF).

Four parents of papaya plants were used. They were chosen based on their genetic values and combining ability; two genotypes belong to group 'Solo' and two to 'Formosa', as described in Table 1.

Table 1. List and description of the genetic material of papaya (Carica papaya L.) used in the experiment.

\begin{tabular}{cccccc}
\hline Access no. in $\mathrm{AGB}^{1}$ & Genotype & Group & Type of material & Origin & Description \\
\hline 202 & 'Sunrise solo-72/12' & Solo & Line & Hawaii - USA & $\begin{array}{l}\text { Fresh weight of fruit: } 0.40 \mathrm{Kg} \text {; } \\
\text { Pulp: orange-red }\end{array}$ \\
20 & 'Waimanalo' & Solo & Line & Hawaii - USA & $\begin{array}{l}\text { Fresh weight of fruit: } 0.55 \mathrm{Kg} \text {; } \\
\text { Pulp: yellow }\end{array}$ \\
206 & 'JS 12' & Formosa & Line & C. do Almeida & $\begin{array}{l}\text { Fresh weight of fruit: } 0.90 \mathrm{Kg} \text {; } \\
\text { Pulp: red }\end{array}$ \\
\hline
\end{tabular}

Source: Caliman Agrícola;UENF

${ }^{1}$ AGB: Active Germplasm Bank

Farm Santa Teresinha was the location of the AGB where the parental crosses were performed under controlled conditions. To obtain hybrid seeds, crosses were performed by means of hand pollination. Hermaphrodite flowers were collected at pre-anthesis; they contained pollen grains which were transferred to the stigma of flowers of female plants by means of the direct contact between these reproductive organs; the female flowers were then protected with paper bags and tagged. The seeds of the parents were produced by means of self-pollination, with the target flowers of hermaphrodite plants being protected. This procedure resulted in 12 treatments (T1 to T12), shown in Table 2.

About seven to eight days after pollination, the protective bags were removed to check whether or not the crosses had been successful. The viable fruits were harvested about five months after pollination, at maturity stage 1 (1/4 of ripe fruit), weighed and left between 7 and 10 days at room temperature, according to Aroucha et al. (2005) and Martins et al. (2006). It is considered that, during this period, the immature seeds complete their full development, reaching maximum germination and vigor.

After the fruits had been left to rest, the seeds were extracted, processed manually in a metal sieve under running water to favor complete removal of the seed coat. Later, they were shade-dried on raised mesh tables until they reached $7-8 \%$ moisture. The evaluation of physical and physiological traits used papaya seeds resulting from the combinations of crosses, self-pollination of the parental lines and control 
cultivars, shown in Table 2, stored for a year, totaling 12 treatments arranged in a completely randomized design with four replications, where the following were evaluated:

Table 2. List of treatments of the experiment: crosses and self-pollination involving four parent genotypes and controls of papaya.

\begin{tabular}{ccc}
\hline Treatments & Pollen receiver $(+)$ & Pollen donor $\left({ }^{\circledR}\right)$ \\
\hline 1 & 'JS12' & 'Sunrise Solo 72/12' \\
2 & 'Sunrise Solo 72/12' & 'JS12' \\
3 & 'JS12' & 'JS12' \\
4 & 'Sekati' & 'Waimanalo' \\
5 & 'JS12' & 'JS12' \\
6 & 'Waimanalo' \\
\hline 7 & 'JS12' $\otimes$ ' \\
8 & 'Sunrise Solo 72/12' $\otimes$ \\
10 & 'Sekati' $\otimes$ \\
\hline \multicolumn{2}{c}{ 'Waimanalo' $\otimes$} \\
\hline 11 & Controls \\
\hline 12 & 'Golden' \\
\hline
\end{tabular}

*self-pollination

a) Water content - determined using two subsamples of $2 \mathrm{~g}$ of seeds of each treatment by the standard oven-drying method (drying at $105 \pm 3{ }^{\circ} \mathrm{C}$ for $24 \mathrm{~h}$ ). The water content of the seeds was expressed on a wet basis (Brasil, 2009).

b) Weight of 1,000 seeds: determined by randomly counting eight subsamples of 100 seeds, which were weighed on a Bioprecisa FA2 $104 \mathrm{~N}$ precision balance $(0.001 \mathrm{~g})$, and the values of the weight of 1,000 seeds were expressed in $\mathrm{g}$, with one decimal place, according to Brasil (2009).

c) Germination test: four replications of 50 seeds were used per treatment, spread along three sheets of Germitest ${ }^{\circledR}$ paper towel, moistened with distilled water at a ratio of 2.5 times the dry weight of the paper. The rolls of paper were placed into polyethylene bags to retain moisture and kept inside BOD incubators at a temperature ranging between 20 and $30{ }^{\circ} \mathrm{C}$ for a photoperiod of $16 / 8$ hours. Germination was evaluated daily, and the seeds considered to be germinated were those with primary root protrusion measuring $\geq 2 \mathrm{~mm}$. The germination percentage was obtained by an evaluation performed at 28 days after sowing, in accordance with the requirements of the Rules for Seed Analysis (Brasil, 2009). The results were expressed as percentages.

d) Test of first germination count (\%): based on the germination test, it considered the percentage of primary root protrusion, obtained at 14 days after sowing.

e) Speed of germination: this test was performed according to the method prescribed for the germination test; seedlings were evaluated daily from the day when the first root protrusion occurred. Speed of germination was calculated using the expression proposed by Edmond and Drapala (1958).

f) Fresh weight and dry weight: at the end of the germination test (28th day after sowing), the normal seedlings were placed in paper bags and taken to an air circulation drying oven at $70{ }^{\circ} \mathrm{C}$ to constant weight. The weight measurements were performed before and after drying to calculate the average fresh weight and average dry weight expressed in mg.seedling ${ }^{-1}$.

g) Seedling emergence in greenhouse: this test was conducted in four replications of 50 seeds treated with Captan (Orthocide $\left(\right.$ ) ) at a dose of $5 \mathrm{~g} \cdot \mathrm{kg}^{-1}$ seed. They were seeded in tubes containing substrate Basaplant ${ }^{\circledR}$ with added Basacot $\AA$ in the proportion of $20 \mathrm{~g}_{\mathrm{kg}} \mathrm{kg}^{-1}$ of substrate, and the trays with plastic tubes were kept in a greenhouse with controlled sprinkler irrigation. The evaluation was made at 28 days after sowing, and the result was expressed as a percentage of emerged seedlings. For the fungicide treatment, the seeds were placed in $23 \times 40$ plastic bags containing Captan and were then shaken until the product was distributed evenly.

The experiment used a completely randomized design with four replications. Data were subjected to analysis of variance, and means were compared by Tukey's test at 5\% probability. The analyses of variance yielded the estimates of variance, broad sense heritability and other genetic parameters by using the software GENES (Cruz, 2006).

\section{Results and Discussion}

The results for water content and weight of 1,000 seeds are summarized in Table 3. This material was homogeneous as regards the water content of the seeds, which ranged from 6.77 to 8.33. According to Meireles et al. (2007), the reduction of the water content of papaya seeds to levels around $6 \%$ gave the best results for germination and vigor. However, the methodology used for drying seeds in this study was efficient to achieve levels of water content close to what is considered ideal for studying the quality of papaya seeds.

Table 3 shows a clear separation between genotypes: seed size for those with greater weight of 1,000 seeds (WTS) is typical of group Formosa, whose seeds are larger, while seeds with smaller WTS typically belong to group Solo. This significant difference was observed taking into account the genotypes under study, whose seeds were derived from crosses in which the female parent is from group Formosa (treatments 1, 3, 4 and 5), as well as self pollinations (treatments 7 and 9), which showed greater values for the weight of 1,000 seeds, unlike the others, with lower values and corresponding to 
the papaya of group Solo (treatments 2, 6, 8, 10 and 11), and treatment 12, of group Formosa. The results obtained for the weight of 1,000 seeds are useful in quantifying the number of seeds per package, estimating the size of the seeds, and estimating their state of maturity and health, in some cases. They can also be used to calculate the seeding rate, which, together with the results of the germination test, can assist seedling producers in making decisions.

Table 3. Averages of weight of 1,000 seeds (g) and water content (\%) of hybrid seeds, self pollination and controls in papaya.

\begin{tabular}{|c|c|c|c|}
\hline Treatments & Cross, self-pollination or control & Seed unit (\%) & Weight of 1,000 seeds $(\mathrm{g})$ \\
\hline 1 & 'JS12' x 'SS72/12' & 8.33 & $19.284 \mathrm{a}^{*}$ \\
\hline 2 & 'SS72/12' x 'JS12' & 7.55 & $11.929 \mathrm{c}$ \\
\hline 3 & 'JS12' x 'Sekati' & 7.80 & $19.014 \mathrm{a}$ \\
\hline 4 & 'Sekati' x 'JS12' & 7.28 & $16.371 \mathrm{a}$ \\
\hline 5 & 'JS12' x 'Waimanalo' & 8.00 & $21.089 \mathrm{a}$ \\
\hline 6 & 'Waimanalo' x 'JS12' & 7.58 & $12.679 \mathrm{c}$ \\
\hline 7 & 'JS12' $\otimes$ & 7.35 & $21.125 \mathrm{a}$ \\
\hline 8 & 'SS72/12' $\otimes$ & 7.32 & $14.835 \mathrm{~b}$ \\
\hline 9 & 'Sekati' $\otimes$ & 7.13 & $16.837 \mathrm{a}$ \\
\hline 10 & 'Waimanalo' $\otimes$ & 8.17 & $12.964 \mathrm{c}$ \\
\hline 11 & 'Golden' & 7.73 & $15.077 \mathrm{~b}$ \\
\hline 12 & 'Tainung 01' & 6.77 & $12.445 \mathrm{c}$ \\
\hline
\end{tabular}

* Means followed by the same letter in the column do not differ by Tukey's test at $5 \%$ probability of error.

The comparison between the F1 hybrids and their reciprocals (Table 3 ) reveals a significant difference between $\mathrm{T} 1$ and $\mathrm{T} 2$ and between $\mathrm{T} 5$ and T6, showing that there was no effect of pollen on the weight of 1,000 seeds, since the averages did not differ significantly from those of the seed parents of treatments 1 and 5, confirming the absence of xenia effect for this attribute. There was no significant difference between T3 and T4, probably because their parents comprise the same group, Formosa. When selfed, cultivar 'SS72/12' also showed a significant difference compared with the reciprocal hybrid 'JS12' x 'SS72/12' (T2), which had lower average weight of 1,000 seeds when pollinated by 'JS12', thus confirming the absence of xenia. In this case, formation of seeds derived from the self-pollination of 'SS72/12' was smaller, favoring the growth and consequently the larger size of such seeds. The lowest averages for weight of 1,000 seeds were observed in the genotype that had the 'Waimanalo' as the female parent and also in the genotypes containing hybrid seeds of Tainung 01 and the reciprocal seeds of hybrid 'JS12' $x$ 'SS72/12'.

According to Manica (1996), 'Tainung 01', F1 hybrid, synthesized at the Experimental Station of Fengshan, Taiwan, has the cultivar 'Sunrise Solo' as the pollen parent and a red pulp cultivar from Costa Rica as the seed parent. The weight of its fruits ranges from 900 to $1,100 \mathrm{~g}$. However, it was observed (Table 3) that the hybrid seeds 'Tainung 01' acquired for this study had one of the smallest weight of 1,000 seeds. Taking into consideration that the hybrid 'Tainung 01 ' originates from group Formosa and, therefore, it has morpho-agronomic and physiological attributes peculiar to this group, it is suggested that the seeds being studied are from a cross in which the female parent was the cultivar 'Sunrise Solo'. As regards seed moisture, Table 3 also shows that homogeneity can be observed among all genotypes, whose levels of water content were considered ideal for studying the quality of papaya seeds.

According to Andrade and Pereira (2005), heterosis, explored in hybrids in general, does not usually appear in $\mathrm{F}_{1}$ seeds (sown by the producer), but rather in plants originating from these seeds. However, Martins et al. (2009), evaluating the effect of pollen on the physical and physiological traits of papaya seeds, reported the absence of xenia for the physical attributes of these seeds, while for the physiological attributes, they highlighted the importance of carrying out controlled pollination for these traits, because of the early manifestation of heterosis.

The analysis of variance showed that there was a significant difference between the means of the genotypes for the seven traits indicative of physiological seed quality. Table 4 shows that $\mathrm{F}_{1}$ hybrids, reciprocals and controls showed higher values for germination (T1, T2, T3, T4, T5, T6, T11 and T12) compared to the selfed parents. However, there was something in particular as regards hybrid 'JS12' $x$ 'SS72/12' (T1), whose germination performance (GERF) was similar to that of line 'JS12'. This shows that this line has better physiological seed quality. A general analysis of the results summarized in Table 4 shows that the selfed line 'SS72/12' consisted of the genotype with lowest vigor and germination performance. Although the use of 'SS72/12' as pollen donor 
in the cross with 'JS12' has originated a hybrid with less vigor (for GERP and SG), it did not affect the physiological quality of the hybrid seeds, if the outcome of GERF, DW, EMERG,
EMERGII is taken into account. In addition, high agronomic potential was observed of hybrids derived from crosses in which one of the parents was 'SS72/12'.

Table 4. Averages of elite hybrids, self pollination and controls of Carica papaya for seven traits associated with seed quality.

\begin{tabular}{clllrrrcc}
\hline Treatment & \multicolumn{1}{c}{ Genotype } & GERP' & GERF & SG & FW & DW & EMERG & EMERGII \\
\hline 1 & 'JS12' x 'SS72/12' & $59.0 \mathrm{c} *$ & $91.5 \mathrm{ab}$ & $11.00 \mathrm{c}$ & $86.75 \mathrm{~cd}$ & $6.50 \mathrm{a}$ & $91.5 \mathrm{a}$ & $93.5 \mathrm{a}$ \\
2 & 'SS72/12'x 'JS12' & $97.0 \mathrm{a}$ & $97.5 \mathrm{a}$ & $7.00 \mathrm{e}$ & $70.75 \mathrm{ef}$ & $4.00 \mathrm{bc}$ & $95.0 \mathrm{a}$ & $95.0 \mathrm{a}$ \\
3 & 'JS12'x 'Sekati' & $94.5 \mathrm{a}$ & $97.5 \mathrm{a}$ & $8.50 \mathrm{~d}$ & $108.75 \mathrm{~b}$ & $5.75 \mathrm{abc}$ & $91.0 \mathrm{a}$ & $97.0 \mathrm{a}$ \\
4 & 'Sekati' x 'JS12' & $90.5 \mathrm{a}$ & $96.5 \mathrm{a}$ & $9.25 \mathrm{~d}$ & $90.75 \mathrm{c}$ & $6.00 \mathrm{abc}$ & $89.0 \mathrm{a}$ & $96.5 \mathrm{a}$ \\
5 & 'JS12'x 'Waimanalo' & $95.5 \mathrm{a}$ & $96.0 \mathrm{a}$ & $7.00 \mathrm{e}$ & $106.50 \mathrm{~b}$ & $5.50 \mathrm{abc}$ & $95.0 \mathrm{a}$ & $96.5 \mathrm{a}$ \\
6 & 'Waimanalo' x 'JS12' & $92.0 \mathrm{a}$ & $94.5 \mathrm{a}$ & $8.75 \mathrm{~d}$ & $80.25 \mathrm{cde}$ & $3.75 \mathrm{c}$ & $89.0 \mathrm{a}$ & $90.5 \mathrm{a}$ \\
7 & 'JS12' $\otimes$ & $77.5 \mathrm{~b}$ & $82.0 \mathrm{bc}$ & $9.25 \mathrm{~d}$ & $124.50 \mathrm{a}$ & $6.00 \mathrm{abc}$ & $69.0 \mathrm{c}$ & $74.5 \mathrm{~b}$ \\
8 & 'SS72/12' $\otimes$ & $13.5 \mathrm{e}$ & $21.0 \mathrm{e}$ & $14.75 \mathrm{a}$ & $74.50 \mathrm{def}$ & $5.75 \mathrm{abc}$ & $12.0 \mathrm{e}$ & $26.5 \mathrm{~d}$ \\
9 & 'Sekati' $\otimes$ & $31.0 \mathrm{~d}$ & $47.5 \mathrm{~d}$ & $13.25 \mathrm{~b}$ & $87.50 \mathrm{~cd}$ & $6.25 \mathrm{ab}$ & $52.0 \mathrm{~d}$ & $63.0 \mathrm{c}$ \\
10 & 'Waimanalo' $\otimes$ & $80.5 \mathrm{~b}$ & $80.5 \mathrm{c}$ & $9.00 \mathrm{~d}$ & $66.25 \mathrm{f}$ & $3.75 \mathrm{c}$ & $73.5 \mathrm{bc}$ & $74.5 \mathrm{~b}$ \\
11 & 'Golden' & $92.5 \mathrm{a}$ & $94.0 \mathrm{a}$ & $7.00 \mathrm{e}$ & $85.25 \mathrm{~cd}$ & $4.50 \mathrm{abc}$ & $86.0 \mathrm{ab}$ & $89.0 \mathrm{a}$ \\
12 & 'Tainung 01' & $94.5 \mathrm{a}$ & $95.0 \mathrm{a}$ & $6.50 \mathrm{e}$ & $82.75 \mathrm{cde}$ & $4.50 \mathrm{abc}$ & $95.5 \mathrm{a}$ & $97.0 \mathrm{a}$ \\
\hline
\end{tabular}

*Means followed by the same letter in the column do not differ by Tukey's test at $5 \%$ probability of error.

${ }^{1}$ GERP: first germination (\%); GERF: germination (\%); SG: speed of germination, FW: seedling fresh weight (mg): DW: seedling dry weight (mg); EMERG: first count of seedling emergence (\%); EMERGII: seedling emergence (\%).

In the first count (GERP), the hybrid, reciprocal and control seeds were generally more vigorous (T2, T3, T4, T5, T6, T11 and T12). However, there was a significant difference of hybrid 'JS12' $x$ 'SS 72/12' (T1) compared to its reciprocal (T2) and the other hybrids, as the former had the lowest vigor (GERP 59\%) of all hybrids evaluated.

There was a significant difference in speed of germination (SG) among the hybrids and their reciprocals, except for the cross of 'JS12' x Sekati, in which T3 and T4 did not differ. The lowest SG occurred in the genotypes of treatments 2, 5, 11 and 12, whose seeds germinated faster. The calculation of SG, based on the formula of Edmond and Drapalla (1958), determines that the shorter the time for germination to occur, the lower the SG. The lines 'JS12' and 'Waimanalo' showed no significant difference in the hybrids from the cross 'JS12' $\mathrm{x}$ Sekati (regardless of the direction of cross) and the reciprocal of the cross 'JS12' $x$ 'Waimanalo', resulting in satisfactory SG, second to the most vigorous ones (T2, T5, T11, T12). These results show the effect of pollen on the embryo and endosperm, which is reflected in the evaluation of the traits of vigor, except for seedling fresh weight (FW). 'JS12' Sekati and 'Waimanalo' can also be referred to as quality pollinators for this trait in the populations under study.

For the variable seedling fresh weight (FW), reciprocal effect was evidenced due to the significant difference observed among hybrids and their reciprocals in all crosses. The evaluation of FW is associated with the ability of the genotype to accumulate water in a given condition. The positive reciprocal effect (RE) at a particular cross shows the contribution of maternal inheritance in controlling the trait under study (Roveri-José et al., 2004). This was evidenced when the line 'JS12' was selfed, with higher average FW (124.50 mg), favoring the superiority of $F_{1}$ hybrids over their reciprocals. This superiority can also be complemented with the observation of seed size, because the $\mathrm{F}_{1}$ hybrids that had the female parent, a genotype of group Formosa, composed the group of large seeds (Table 3), with a seed size similar to that of 'JS12', a line from group Formosa. The size of the seeds is evidence of greater water absorption and translocation of reserves to them. As for FW, the choice of the parent (sometimes as female, sometimes as male) was essential to distinguish the $\mathrm{F}_{1}$ hybrid from its reciprocal (Table 4).

There was a significant difference for the variable seedling dry weight (DW) between the hybrid 'JS12' x 'SS 72/12' (6.50 $\mathrm{mg}$ ) and its reciprocal $(4.00 \mathrm{mg})$, but such difference was not evident among the other genotypes, except when compared to the hybrid 'Waimanalo' $x$ 'JS12'. The relationship between seed size and dry weight was also observed, wherein the genotypes with the lowest DW values (3.75 to $4.50 \mathrm{mg}$ ) correspond to the group of small seeds. Costa et al. (2006) and Silva et al. (2010) observed greater vigor in larger fruit seeds.

Based on estimates of the correlation coefficients (Table 5), it can be seen that the correlations between weight of 1,000 seeds (WTS) and other variables were generally low. However, significant and positive genetic correlation was observed between WTS and FW and between WTS and DW, showing the influence of the size of papaya seeds in seedling 
development. Furthermore, the genotypic correlation was higher than the phenotypic one in both correlations, which is favorable to the selection process, because the genetic effects outweigh the environmental ones in the phenotypic expression. This was also observed in studies with passion fruit (Araújo et al., 2007) and papaya (Oliveira et al., 2010).

Table 5. Estimates of correlation (Rf), genotypic ( $\mathrm{Rg}$ ) and environmental (Ra) coefficients among eight physical traits and physical and physiological quality traits of Carica papaya seeds.

\begin{tabular}{|c|c|c|c|c|c|c|c|c|}
\hline Trait $^{1}$ & & GERF & $\mathrm{SG}$ & FW & DW & EMERG & EMERG II & WTS \\
\hline \multirow{3}{*}{ GERP } & $\mathrm{Rf}$ & $0.94 * *$ & $-0.96 * *$ & 0.19 & -0.50 & $0.90 * *$ & $0.88 * *$ & -0.08 \\
\hline & $\mathrm{Rg}$ & 0.94 & -0.97 & 0.19 & -0.59 & 0.91 & 0.89 & -0.08 \\
\hline & $\mathrm{Ra}$ & 0.75 & -0.24 & 0.03 & 0.38 & -0.04 & -0.02 & 0.10 \\
\hline \multirow{3}{*}{ GERF } & $\mathrm{Rf}$ & & $-0.88^{* *}$ & 0.22 & -0.33 & $0.98 * *$ & $0.97 * *$ & 0.04 \\
\hline & $\mathrm{Rg}$ & & -0.89 & 0.23 & -0.39 & 0.99 & 0.98 & 0.04 \\
\hline & $\mathrm{Ra}$ & & 0.14 & -0.16 & 0.41 & -0.04 & -0.02 & 0.05 \\
\hline \multirow{3}{*}{ SG } & $\mathrm{Rf}$ & & & -0.11 & 0.55 & $-0.86^{* *}$ & $-0.83 * *$ & 0.16 \\
\hline & $\mathrm{Rg}$ & & & -0.11 & 0.63 & -0.87 & -0.83 & 0.16 \\
\hline & $\mathrm{Ra}$ & & & -0.30 & 0.12 & -0.03 & -0.20 & 0.09 \\
\hline \multirow{3}{*}{ FW } & $\mathrm{Rf}$ & & & & 0.53 & 0.17 & 0.22 & $0.86^{* *}$ \\
\hline & $\mathrm{Rg}$ & & & & 0.61 & 0.17 & 0.22 & 0.87 \\
\hline & $\mathrm{Ra}$ & & & & 0.08 & 0.03 & 0.18 & -0.16 \\
\hline \multirow{3}{*}{ DW } & $\mathrm{Rf}$ & & & & & -0.28 & -0.20 & $0.74 * *$ \\
\hline & $\mathrm{Rg}$ & & & & & -0.32 & -0.22 & 0.84 \\
\hline & $\mathrm{Ra}$ & & & & & -0.01 & -0.01 & -0.04 \\
\hline \multirow{3}{*}{ EMERG } & $\mathrm{Rf}$ & & & & & & $0.99 * *$ & 0.02 \\
\hline & $\mathrm{Rg}$ & & & & & & 0.99 & 0.02 \\
\hline & $\mathrm{Ra}$ & & & & & & 0.82 & -0.05 \\
\hline \multirow{3}{*}{ EMERG II } & $\mathrm{Rf}$ & & & & & & & 0.07 \\
\hline & $\mathrm{Rg}$ & & & & & & & 0.07 \\
\hline & $\mathrm{Ra}$ & & & & & & & -0.24 \\
\hline
\end{tabular}

${ }^{1}$ GERP: first germination count (\%); GERF: germination (\%); SG: speed of germination; FW: seedling fresh weight (mg); DW: seedling dry weight (mg); EMERG: first count of seedling emergence (\%); EMERGII: seedling emergence (\%); WTS: weight of 1,000 seeds (g).

According to Santos et al. (2009), the endosperm of papaya seeds is rich in lipids and aleurone layers, while the cotyledons and embryo axis contain more starch granules and fewer lipids as compared to the endosperm. As the aleurone layer is constitutive of the endosperm, hence resulting from fertilization, the phenotypic expression of traits that appear in the endosperm may occur, as well as the xenia phenomenon, which can be considered as the effect of pollen on the embryo and endosperm (Andrade and Pereira, 2005), altering their genetic traits and providing qualitative and quantitative changes.

Based also on the traits of physiological seed quality (Table 4), there is the influence of pollen on the seeds, indicating the action of the xenia effect, whereby an heterotic increase can be explored. $82 \%$ of the seeds of selfed 'JS12' were germinated, and when 'JS12' was the female parent and Sekati or 'Waimanalo' were the pollen donors at a cross, the hybrid seeds from such crosses had improved germination performance ( $97.5 \%$ and $96 \%$ respectively), which was also observed for vigor, based on GERP.

However, in the same condition in which 'JS12' had 'SS72/12' as its pollen donor, the germination performance of the hybrid seed derived from this cross was similar to that of line 'JS12' (91.5\% and 82\% respectively) but vigor was lesser (GERP 59\%). Because for the first count (vigor) in the latter case, the xenia effect was negative, as line 'JS12' (GERP $77.5 \%$ ) was pollinated by line 'SS72/12', which showed less vigor considering the value of GERP (13.5\%). According to Andrade and Pereira (2005), the same effect in the $F_{1}$ 
hybrid may not be shown in the reciprocal cross, because the ratio between the maternal and paternal genomes in the triploid endosperm is different. Combined with the genetic effects found in the loci controlling this trait and also with a possible maternal effect, this can cause different xenia effects among reciprocals.

Accordiwng to Denney (1992), the results of xenia can be interpreted as an early manifestation of heterosis. This manifestation was shown for the traits GERP, GERF and SG, since the means for $F_{1}$ seed germination were higher than the average of the parents and non-similar seeds. When the lines 'SS72/12' Sekati and 'Waimanalo' were pollinated by 'JS12', the $\mathrm{F}_{1}$ generation seeds had a clear heterotic increase.

The most sensitive vigor tests to detect the expression of the reciprocal effect (ER) in the studied crosses were seedling SG and seedling FW. RE was observed at the cross 'JS12' $\mathrm{x}$ 'SS72/12' through the following vigor tests: GERP, SG, FW and DW. ER was expressed in the last three variables in hybrid 'JS12' x 'Waimanalo'. And in hybrid 'JS12' x Sekati, ER was expressed only on the vigor trait FW, where ER can be explained exclusively by the maternal effect.

As for seed production, producing hybrid combinations is feasible in both directions: F1 and its reciprocal. Physiologically, they are both viable. From the perspective of seed size, the determining factor is the female parent. If a 'Solo' parent is used as a female, the F1 seeds are small, which is typical of group 'Solo'; if the female parent is from group 'Formosa', the seeds are larger, which is typical of group 'Formosa'.

Table 6 shows that the phenotypic variation results from the combined effect of the genotype $\left(\sigma_{\mathrm{g}}^{2}\right)$ and the environment $\left(\sigma^{2}{ }_{e}\right)$. One aspect of environmental variation is that it may occur due to environmental differences to which individuals are subjected. However, this study of physiological seed quality sought to control the maximum environmental changes, which was evidenced in the low values of $\sigma$ ${ }^{2}$. Higher values for $\sigma^{2}$ are indicative of greater genetic variability, which will enable the identification of superior genotypes, because it is used to obtain other parameters, e.g., heritability (Cruz and Carneiro, 2003). In this study, the heritability values are predominantly very high, close to that of the unit, and, thus, indicative that virtually all the differences among the means are attributed to genetic causes.

Table 6. Estimates of phenotypic $\left(\sigma^{2}{ }_{\mathrm{ph}}\right)$, environmental $\left(\sigma_{\mathrm{e}}^{2}\right)$ and genotypic $\left(\sigma_{\mathrm{g}}^{2}\right)$ variance; coefficient of genetic variation $(\mathrm{CV})$; experimental coefficient of variation $\left(\mathrm{CV}_{\mathrm{e}}\right)$, the relationship between the coefficient of genotypic and experimental variation $\left(\mathrm{CV}_{\mathrm{g}} / \mathrm{CV}_{\mathrm{e}}\right)$ and broad-sense heritability $\left(\mathrm{h}^{2}\right)$ for seven traits associated with seed quality of elite hybrids and self-pollination of papaya.

\begin{tabular}{crrrrrrr}
\hline Trait $^{1}$ & \multicolumn{1}{c}{$\sigma^{2}{ }_{\mathrm{ph}}$} & $\sigma^{2}{ }_{\mathrm{e}}$ & \multicolumn{1}{c}{$\sigma_{\mathrm{g}}{ }_{\mathrm{g}}$} & $\mathrm{CV}_{\mathrm{g}}$ & $\mathrm{CV}_{\mathrm{e}}$ & $\mathrm{CV}_{\mathrm{g}} / \mathrm{CV}_{\mathrm{e}}$ & $\mathrm{h}^{2}$ \\
\hline GERP & 865.38 & 4.03 & 861.35 & 40.15 & 5.25 & 7.31 & 99.53 \\
GERF & 669.19 & 4.09 & 665.10 & 32.06 & 4.89 & 6.38 & 99.39 \\
SG & 6.63 & 0.05 & 6.58 & 26.37 & 4.96 & 5.60 & 99.21 \\
FW & 344.49 & 6.92 & 337.57 & 20.50 & 5.93 & 3.49 & 97.99 \\
DW & 1.10 & 0.22 & 0.88 & 18.05 & 18.45 & 0.99 & 79.96 \\
EMERG & 694.62 & 9.06 & 685.56 & 34.59 & 7.70 & 4.35 & 98.69 \\
EMERG II & 506.35 & 4.67 & 501.67 & 27.74 & 5.22 & 5.18 & 99.07 \\
\hline
\end{tabular}

${ }^{1}$ GERP: first germination (\%); GERF: germination (\%); SG: speed of germination, FW: seedling fresh weight (mg): DW: seedling dry weight (mg); EMERG: first count of seedling emergency (\%); EMERGII: seedling emergence (\%).

The highest coefficient of genetic variation $\left(\mathrm{CV}_{\mathrm{g}}\right)$ was observed for the trait GERP (40.15\%), and the lowest one for DW $(18.05 \%)$. This range of values, taking into account the other traits, is further evidence of significant genetic variability. It was also found that the experimental coefficient of variation $\left(\mathrm{CV}_{\mathrm{e}}\right)$ showed satisfactory values for all the tests, indicating the precision in conducting the experiment. Nearly the whole of the $\mathrm{CV}_{\mathrm{g}} / \mathrm{CV}_{\mathrm{e}}$ ratio was much larger than one, which corroborates the the indication of success in selection procedures for the variables considered here.

\section{Conclusions}

The xenia effect can be explored in the characteristics of germination and vigor.

The selfed line 'SS72/12' of papaya is the genotype with the lowest vigor and germination performance.

The most sensitive vigor tests to discriminate the expression of reciprocal effect in papaya crosses are speed of germination and seedling fresh weight.

Seed size can influence the development of papaya seedlings.

From the standpoint of seed size, the female parent is the determining factor. 
From the standpoint of physiology and seed production, producing hybrid combinations is feasible in both directions, $\mathrm{F}_{1}$ and its reciprocal.

\section{Acknowledgements}

The authors would like to thank FAPERJ (Research Support Foundation of the State of Rio de Janeiro) for funding the project, UENF (Universidade Estadual do Norte Fluminense) for granting a $\mathrm{PhD}$ scholarship to the first author, and agronomist Geraldo Antonio Ferreguetti for providing the seeds with the support of the company Caliman Agrícola S.A.

\section{References}

ANDRADE, J.A.C.; PEREIRA, F.C.D. Uso do efeito xênia em híbridos comerciais de milho (Zea mays L.). Revista Brasileira de Milho e Sorgo, v.4, n.1, p.65-78, 2005. http://rbms.cnpms.embrapa.br/index.php/ojs/article/view/128/128

ARAÚJO, E.C.; DAHER, R.F.; SILVA, R.F.; VIANA, A.P. Path analysis for physiological traits that influence seed germination of Passiflora edulis $\mathrm{f}$. Alavicarpa Deg. Crop Breeding and Applied Biotechnology, v.7, p.148-154, 2007. http://www.sbmp.org.br/cbab/siscbab/uploads/bd6b8831-069d-5997.pdf

AROUCHA, E.M.M.; SILVA, R.F.; OLIVEIRA, J.G.; VIANA, A.P.; PEREIRA, M.G. Época de colheita e período de repouso de frutos de mamão (Carica papaya L.) cv. Golden na qualidade fisiológica das sementes. Ciência Rural, v.35, n.3, p.537-543, 2005. http://www.scielo.br/pdf/cr/v35n3/a08v35n3.pdf

BERBERT, P.A.; CARLESSO, V.O.; SILVA, R.F.; ARAÚJO, E.F.; THIÉBAUT, J.T.L.; OLIVEIRA, M.T.R. Qualidade fisiológica de semente de mamão em função da secagem e do armazenamento. Revista Brasileira de Sementes, v.30, n.1, p.40-48, 2008. http://www.scielo.br/pdf/rbs/v30n1/a06v30n1.pdf

BRASIL. Ministério da Agricultura, Pecuária e Abastecimento. Regras para análise de sementes. Ministério da Agricultura, Pecuária e Abastecimento. Secretaria de Defesa Agropecuária. Brasília: MAPA/ACS, 2009. 395p. http:// www.bs.cca.ufsc.br/publicacoes/regras\%20analise\%20sementes.pdf

CARDOSO, D.L.; SILVA, R.F.; PEREIRA, M.G.; VIANA, A.P.; ARAÚJO, E.F. Diversidade genética e parâmetros genéticos relacionados à qualidade fisiológica de sementes em germoplasma de mamoeiro. Revista Ceres, v.56, n.5, p.572-579, 2009. http://www.ceres.ufv.br/ceres/revistas/v56n005p04108.pdf

COSTA, R.S.; OLIVEIRA, I.V.M.; MÔRO, F.V.; MARTINS, A.B.G. Aspectos morfológicos e influência do tamanho da semente na germinação do jambo-vermelho. Revista Brasileira de Fruticultura, v.28, n.1, p.117-120, 2006. http://www.scielo.br/pdf/rbf/v28n1/29706.pdf

CRUZ, C.D. Programa Genes: análise multivariada e simulação. Viçosa: Universidade Federal de Viçosa, 2006. 175p.

CRUZ, C.D.; CARNEIRO, P.C.S. Modelos biométricos aplicados ao melhoramento genético. Viçosa: UFV, 2003. v.2. 585p.

DENNEY, J.O. Xenia includes metaxenia. HortScience, v.27, n.7, p.722-728, 1992. http://hortsci.ashspublications.org/content/27/7/722.full.pdf + html
EDMOND, J.B.; DRAPALA, W.J. The effects of temperature, sand and soil, and acetone on germination of okra seed. Proccedings of American Society Horticultural Science, v.71, p.428-434, 1958.

INSTITUTO BRASILEIRO DE GEOGRAFIA E ESTATÍSTICA - IBGE. Produção agrícola Municipal. Accessed on: Dec. $18^{\text {th }}$ 2011. http://www.ibge. gov.br/home/estatistica/economia/pam/2009/pam2009_comentarios.pdf

LOPES, J.C.; COELHO, R.I.; BREGONCI, I.S.; MACEDO, C.M.P.; MAIA, L.R. Brotação de mamoeiro Tainung 1 submetido a diferentes alturas de corte do caule. Ciência e Agrotecnologia, v.32, n.2, p.360-365, 2008. http://www. scielo.br/pdf/cagro/v32n2/02.pdf

MANICA, I. Cultivares e melhoramento do mamoeiro. In: MENDES, L.G.; DANTAS, J.L.L.; MORALES, C.F.G. Mamão no Brasil. Cruz das Almas, BA: EUFBA/EMBRAPA-CNPMF, p.93-120. 1996.

MARIN, S.L.D.; PEREIRA,M.G.; AMARAL JUNIOR, A.T.; MARTELLETO, L.A.P.; IDE, C.D. Heterosis in papaya hibrids from partial diallel of 'Solo' and 'Formosa' parents. Crop Breeading Applied Biotechnology, v.6, p.24-29, 2006. http://www.sbmp.org.br/cbab/siscbab/ uploads/c8eb9792-79e5-5f23.pdf

MARTINS, G.N.; PEREIRA, M.G.; SILVA, R.F.; OLIVEIRA, A.C.S.; SILVA, F. Efeito do pólen nas características físicas e fisiológicas de sementes de mamão. Revista Brasileira de Sementes, v.31, n.2, p. 19-26, 2009. http:// www.scielo.br/pdf/rbs/v31n2/v31n2a02.pdf

MARTINS, G.N.; SILVA, R.F.; PEREIRA, M.G.; ARAÚJO, E.F.; POSSE, S.C.P. Influência do repouso pós-colheita de frutos na qualidade fisiológica de sementes de mamão. Revista Brasileira de Sementes, v.28, n.2, p.142-146, 2006. http://www.scielo.br/pdf/rbs/v28n2/a19v28n2.pdf

MEIRELES, R.C.; SILVA, R.F.; BERBERT, P.A.; ARAÚJO, E.F.; REIS, L.S.; CARLESSO, V.O. Efeito imediato do teor de água e do tipo de secagem sobre a qualidade fisiológica das sementes de mamoeiro. In: OLIVEIRA, J.G.; VIANA, A.P.; PEREIRA, M.G. (Eds.) Boletim Técnico da III Reunião de Pesquisa do Futimamão. Campos dos Goytacazes: Universidade Estadual do Norte Fluminense Darcy Ribeiro, p. 256-258, 2007.

OLIVEIRA, E.J.; LIMA, D.S.; LUCENA, R.S.; MOTTA, T.B.N.; DANTAS, J.L.L. Correlações genéticas e análise de trilha para número de frutos comerciais por planta em mamoeiro. Pesquisa Agropecuária Brasileira, v.45, n.8, p.855-862, 2010. http://www.scielo.br/pdf/pab/v45n8/v45n8a11.pdf

ROVERI JOSÉ, S.C.B.; VON PINHO, E.V.R.; VON PINHO, R.G.; RAMALHO, M.A.P.; SILVA FILHO, J.L. Controle genético da tolerância à alta temperatura de secagem em sementes de milho. Revista Brasileira de Milho e Sorgo, v.3, n.3, p.414-428, 2004. http://rbms.cnpms.embrapa.br/ index.php/ojs/article/view/119/119

SANTOS, S.A.; SILVA, R.F.; PEREIRA, M.G.; ALVES, E.; MACHADO, J.C.; BORÉM, F.M.; GUIMARÃES, R.M.; MARQUES, E.R. Estudos morfo-anatômicos de sementes de dois genótipos de mamão (Carica papaya L.). Revista Brasileira de Sementes, v.31, n.2, p.116-122, 2009. http://www. scielo.br/pdf/rbs/v31n2/v31n2a13.pdf

SILVA, K.S.; MENDONÇA, V.; MEDEIROS, L.F.; FREITAS, P.S.C.; GÓIS, G.B. Influência do tamanho da semente na germinação e vigor de mudas de jaqueira (Artocarpus heterophyllus Lam.). Revista Verde de Agroecologia e Desenvolvimento Sustentável, v.5, n.4, p.217-221, 2010. http://www.gvaa. com.br/revista/index.php/rvads/article/viewfile/359/pdf_35 